\title{
Characterization of microbe cementitious materials
}

\author{
RONG Hui ${ }^{1,2} \&$ QIAN ChunXiang ${ }^{1,2 *}$ \\ ${ }^{1}$ School of Materials Science and Engineering, Southeast University, Nanjing 211189, China; \\ ${ }^{2}$ Jiangsu Key Laboratory of Construction Material, Nanjing 211189, China
}

Received August 1, 2011; accepted September 19, 2011

\begin{abstract}
A new generation of cement, microbe cement, has been developed in response to the ever increasing awareness of environmental protection. Microbe cement is a new strengthening material based on microbiologically induced precipitation of calcium carbonate. This paper confirms the feasibility of binding loose sand particles using microbe cement and details the cementation mechanism of microbe cement. We have also prepared microbe cementitious materials (biosandstones). The compressive strength of the bio-sandstone, which depends on the content of calcium carbonate produced by microbially induced precipitation and the bio-mediated calcite crystal size, could be up to $12 \mathrm{MPa}$ at an age of 20 days. By increasing the precipitated calcite content, the compressive strength and microstructure of bio-sandstone could be improved.
\end{abstract}

microbe cement, cementation mechanism, microstructure, calcite

Citation: $\quad$ Rong H, Qian C X. Characterization of microbe cementitious materials. Chin Sci Bull, 2012, 57: 1333-1338, doi: 10.1007/s11434-012-5047-9

The cement industry has for some time been seeking procedures that would effectively reduce the high energy requirements and environmental costs of cement manufacture. One such procedure is the use of alternative materials for cementation of loose particles. In recent years, microbe cement, which only consists of three materials: alkalophilic microbes, substrate solution and calcium ion solution, has experienced an increased level of interest. This type of process is more environmentally friendly than conventional treatment methods and often occurs in naturally cemented deposits. The method relies on the bacterially induced formation of a compatible carbonate precipitate around individual particles and at particle-particle contacts.

The great promise of the use of microbe cement treatment has been demonstrated in a variety of fields. Several researchers have shown that microbe cement can be used to improve the mechanical properties (cohesion, friction, stiffness, strength) and decrease the permeability of porous materials [1-7]. Moreover, microbe cement has been investigated for its potential to reinforce or repair construction materials such as limestone and cement-based materials or

\footnotetext{
*Corresponding author (email: cxqian@seu.edu.cn)
}

concretes [8-12]. A series of studies has been aimed at modifying the properties of soil or sand $[2,13,14]$ while other work has targeted the field of bioremediation [15-19].

In this paper, first, the cementation mechanism of microbe cement is discussed in detail. Microbe cementitious materials have then been prepared and the properties of representative samples have been analyzed by scanning electron microscopy (SEM) and mercury intrusion analysis (MIP). Finally, the relationship amongst compressive strength, porosity and calcium carbonate content has been established.

\section{Cementation mechanism of microbe cement}

Microbe cement has been proposed as a novel method for cementing loose sands to produce structural materials. This process of cementation has a complex mechanism. First, the substrate solution is broken down into carbon dioxide by the bacterially-produced urease according to the reaction [20-22]

$$
\text { Substrate } \mathrm{B}+3 \mathrm{H}_{2} \mathrm{O} \stackrel{\text { Bacteria }}{\longrightarrow} \mathrm{CO}_{3}{ }^{2-} \text {. }
$$

Second, the value of $\mathrm{pH}$ of the surrounding environment is 
increased through the breakdown of the substrate. In the meantime, in the presence of calcium ions, the following reactions are triggered $[3,22,23]$ :

$$
\begin{gathered}
\mathrm{Ca}^{2+}+\mathrm{HCO}_{3}^{-}+\mathrm{OH}^{-} \rightarrow \mathrm{CaCO}_{3} \downarrow+\mathrm{H}_{2} \mathrm{O}, \\
\mathrm{Ca}^{2+}+2 \mathrm{HCO}_{3}^{-} \Leftrightarrow \mathrm{CaCO}_{3} \downarrow+\mathrm{CO}_{2}+\mathrm{H}_{2} \mathrm{O} .
\end{gathered}
$$

Ions diffuse through the cell wall of the microbe and into the surrounding solution. Two reactions spontaneously occur in the presence of water; ammonia is converted to ammonium and carbon dioxide equilibrates in a pH-dependent manner with carbonic acid, carbonate and bicarbonate ions. The net increase in $\mathrm{pH}$ is due to the hydroxyl ions generated from the production of $\mathrm{NH}_{4}{ }^{+}$which exceeds the $\mathrm{Ca}^{2+}$ available for calcite precipitation.

$\mathrm{CaCO}_{3}$ precipitation requires sufficient calcium and carbonate ions so that the ion activity product exceeds the solubility constant (eqs. (4) and (5)). From the comparison of the ion activity with the solubility constant, the saturation state $(\Omega)$ of the system can be defined: if $\Omega>1$ the system is oversaturated and precipitation is likely [23]:

$$
\begin{gathered}
\mathrm{Ca}^{2+}+\mathrm{CO}_{3}{ }^{2-} \Leftrightarrow \mathrm{CaCO}_{3} \downarrow, \\
\Omega=\alpha\left(\mathrm{Ca}^{2+}\right) \alpha\left(\mathrm{CO}_{3}{ }^{2-}\right) / K_{\text {SO }} \text { with } K_{\text {SO calcite, } 25^{\circ}}=4.8 \times 10^{-9} .
\end{gathered}
$$

In addition to calcite precipitation from the above mechanism, calcium ions deposit on the surface of microorganisms which have a negative net cell surface charge. The equations for the precipitation of calcite when the cell surface serves as the nucleation site are as follows [3,24]:

$$
\begin{gathered}
\mathrm{Ca}^{2+}+\mathrm{Cell} \rightarrow \text { Cell }-\mathrm{Ca}^{2+}, \\
\mathrm{Cell}-\mathrm{Ca}^{2+}+\mathrm{CO}_{3}{ }^{2-} \rightarrow \text { Cell }-\mathrm{CaCO}_{3} \downarrow .
\end{gathered}
$$

De Muynck et al. [8] have explained this clearly. First, calcium ions in the solution are attracted to the bacterial cell wall because of the negative charge of the latter and upon addition of substrate to the bacteria. Second, in the presence of calcium ions, this can result in a local supersaturation and hence heterogeneous precipitation of calcium carbonate on the bacterial cell wall. After a while, the whole cell becomes encapsulated, limiting nutrient transfer and resulting in cell death. Finally, the formation of calcite crystals by biomediated processes at the particle surfaces becomes so extensive that the particles are coated or bridges and the loose sands become a single mass. The microbe cement could play a part in the cementation function as described above. The state before and after cementing loose sands is given in Figure 1. When the non-compact sands are put into the injector, there are lots of inter-particle spaces between the grains as shown in Figure 2(a). The bacteria solution is first introduced into the sand and after the solution is fully exudative, numerous thalli will remain on the surface of sand as shown in Figure 2(b). Then the mixture of substrate and calcium ion solution is injected, and the cementation substance will be produced through bio-mineralization. The cementation substance will attach to the sand surface, and will enwrap the bacteria as its content increases (shown in

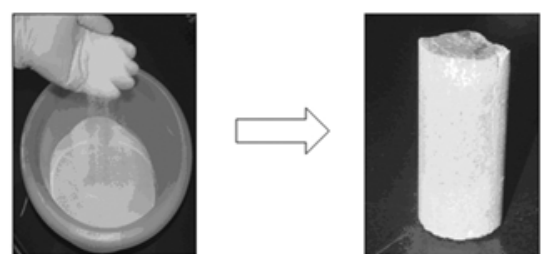

Figure 1 Loose sand to sandstone cemented by microbe cement.
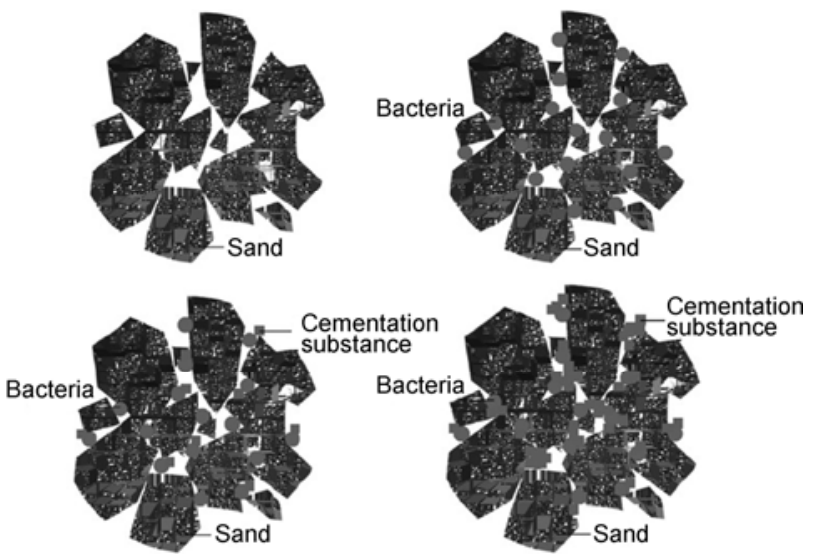

Figure 2 Cementation mechanism of microbe cement. (a) Loose sand; (b) microbe absorbed in the surface of loose sand; (c) cementation substance absorbed in the surface of loose sand; (d) loose sand to whole sand cemented by microbe cement.

Figure 2(c)). Through this process, new $\mathrm{CaCO}_{3}$ will form on top of older layers, until the adjacent sand grains are connected to form a whole sand body with a certain degree of strength as in Figure 2(d) [25].

\section{Experiments and methods}

\subsection{Materials}

(i) Microbe cement. Microbe cement only consists of three materials: alkalophilic microbes, substrate solution and calcium ion solution. A microbial culture with optical density (at $600 \mathrm{~nm}$ wavelength) value of 1.7 and enzyme urease activity value of $4.4 \mathrm{mmol} /(\mathrm{L} \mathrm{min})$ was used in this study. Cultivation of the organism was conducted in a medium containing $3 \mathrm{~g} / \mathrm{L}$ yeast extract and $5 \mathrm{~g} / \mathrm{L}$ peptone. In general, the harvested microorganisms were stored at $4{ }^{\circ} \mathrm{C}$ prior to use. The concentrations of substrate solution and calcium ion solution were $2 \mathrm{~mol} / \mathrm{L}$.

(ii) Aggregate. The aggregate used in this study was quartz sand (grain size characteristics: $d_{10}=150 \mu \mathrm{m}$ (10\% of the grains were smaller than this diameter); $d_{90}=300 \mu \mathrm{m}$ ).

\subsection{Column parameters and molding technique}

The $50 \mathrm{~mL}$ plastic syringes (internal diameter $3.0 \mathrm{~cm}$, length $11.0 \mathrm{~cm}$ ) were used (Figure 3). The columns were packed in the following order: first a layer of approximately $1.0 \mathrm{~cm}$ of gauze was placed at bottom of the syringes, 

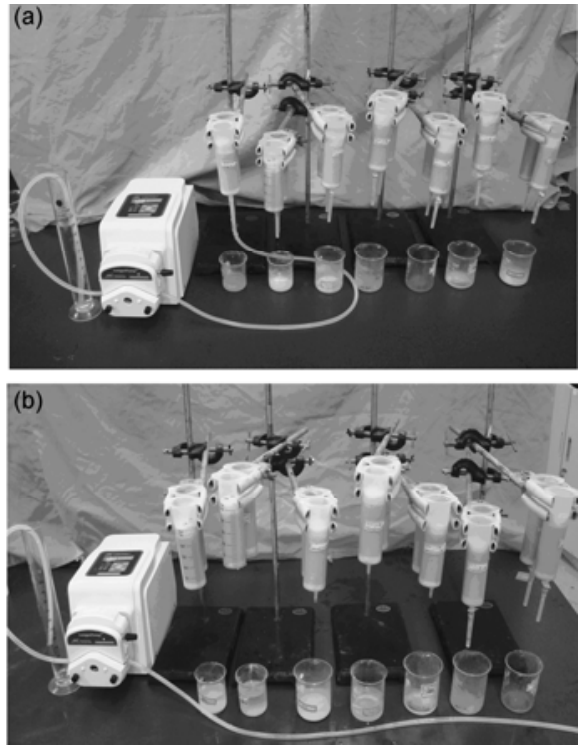

Figure 3 Experimental apparatus for cementation of loose sands using microbe cement.

followed by $6.0 \mathrm{~cm}$ of quartz sand. Packing was performed under water to avoid the inclusion of air pockets. On top of the sand another layer of approximately $1.0 \mathrm{~cm}$ of gauze sheet was placed. The column was closed and positioned vertically. Before experiments were conducted, tap water was flushed through the sands two or three times to drive away the extra air. All experiments were performed at ambient temperature of $30 \pm 2^{\circ} \mathrm{C}$.

The molding technique was performed as follows: first, a pump that could regulate the flow rate was connected to an injection point at the bottom of the column. Second, microbial solution was injected into the sand at a constant flow rate of $5 \mathrm{~mL} / \mathrm{min}$. When the microbial solution was fully loaded into the sand, the flow was stopped for $2 \mathrm{~h}$ to fix more bacteria to the sand. After $2 \mathrm{~h}$ of fixation time the cementation solution was flushed through the sand at a stable flow rate of $10 \mathrm{~mL} / \mathrm{min}$. After the first batch of cementation fluid was injected into the sand column, the flow was paused for $2 \mathrm{~h}$. After $2 \mathrm{~h}$ of reaction time a second batch of cementation solution was flushed through the sand column. The fluid in the column was then allowed to react for $12 \mathrm{~h}$. The above steps were repeated until no fluid leaked out.

\subsection{Specimen preparation}

The cylindrical specimens, $30 \mathrm{~mm}$ diameter $\times 60 \mathrm{~mm}$ long were cast to determine the compressive strength. The mix design of the bio-sandstone was as described in Table 1. After casting, the specimens were kept at $30 \pm 2^{\circ} \mathrm{C}$ until testing. After about $20 \mathrm{~d}$, the samples of sand body were successfully consolidated as shown in Figure 4.

\subsection{Testing of mechanical properties}

At age 20 days, when all the specimens should have equal

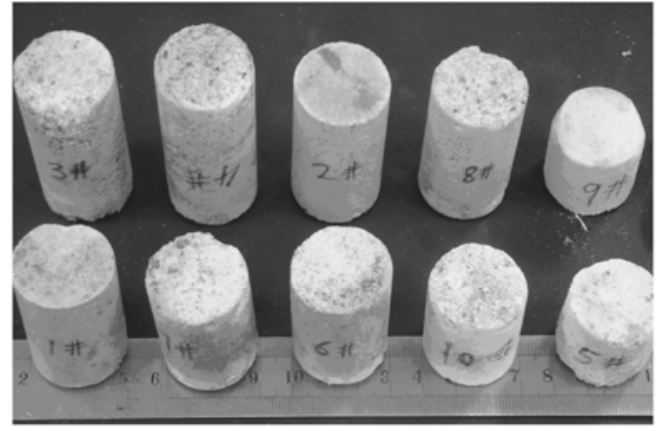

Figure 4 Samples of sandstone cemented by microbe cement.

Table 1 Mix design of the bio-sandstone

\begin{tabular}{cc}
\hline Constituents & Amounts \\
\hline Microbe solution & $200 \mathrm{~mL}$ \\
Substrate solution & $100 \mathrm{~mL}$ \\
Calcium ion solution & $100 \mathrm{~mL}$ \\
Quartz sand & $80 \mathrm{~g}$ \\
\hline
\end{tabular}

maturity, the compressive strengths of the column samples were tested using a loading rate of $1 \mathrm{~mm} / \mathrm{min}$.

\subsection{Testing of porous structure}

The pore size distribution test was performed using a Micromeritics Auto-Pore IV 9500 with sufficiently large pressure range up to $415 \mathrm{MPa}$. Before testing, the samples were dried at $60^{\circ} \mathrm{C}$ for $24 \mathrm{~h}$.

\subsection{Calcium carbonate content}

After the mechanical property tests, the precipitated calcium carbonate content in the bio-sandstone samples was measured. First, $M_{\text {dry }}$ was recorded according to the porosity measurement. Second, the dried bio-sandstone was mixed with an excess of $\mathrm{HCl}$; after sufficient time for chemical reaction, the superfluous fluid was removed by filtration, and the residual matter was dried to give mass $M_{\text {residual }}$. Finally, the calcium carbonate content was determined using the following formula:

$$
M_{\text {calcite }}=M_{\text {dry }}-M_{\text {residual }} .
$$

\section{Results and discussion}

\subsection{Compressive strengths of microbe cementitious materials}

The compressive strength results for representative sandstones cemented by microbe cement are shown in Figure 5. Figure 5(a) shows that sample 2\# bio-sandstone had the 


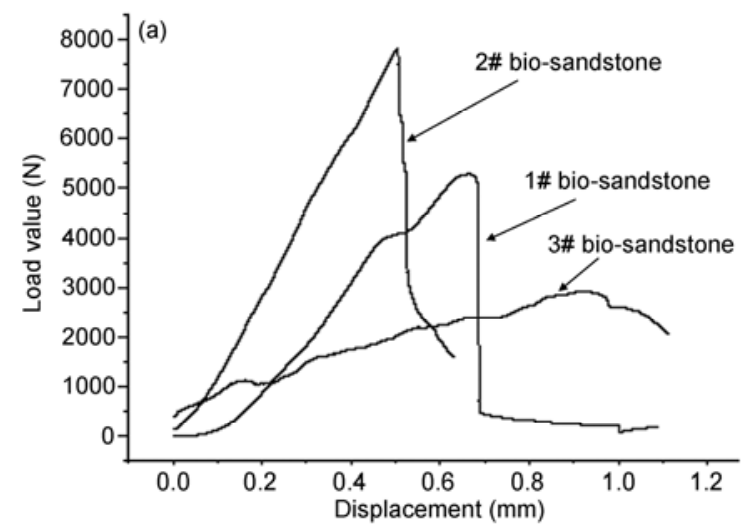

(b)
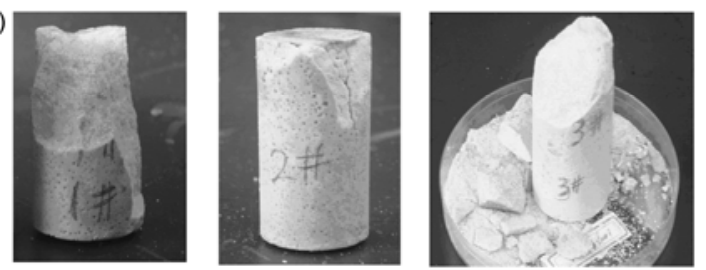

Figure 5 Load-deformation curves and failure modes of bio-sandstones at age 20 days. (a) Load-deformation of bio-sandstone; (b) failure modes of bio-sandstone.

(a)

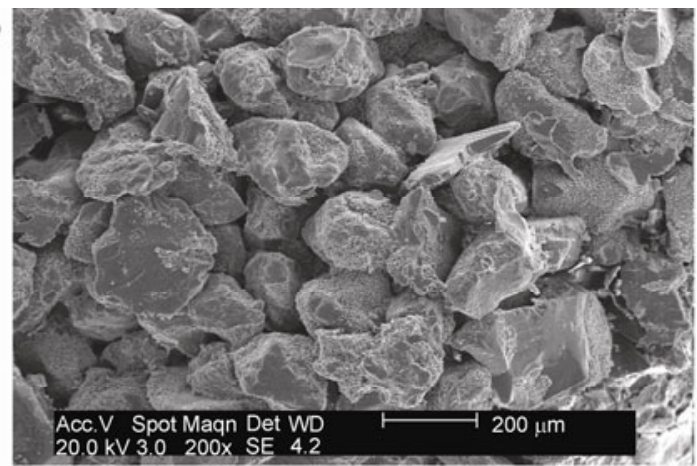

(b)

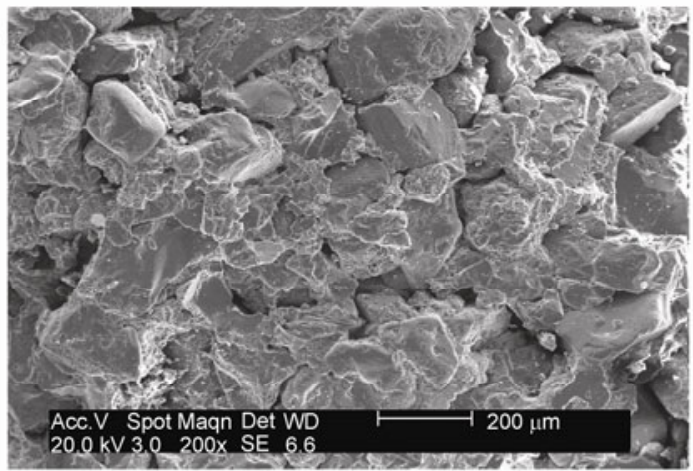

(c)

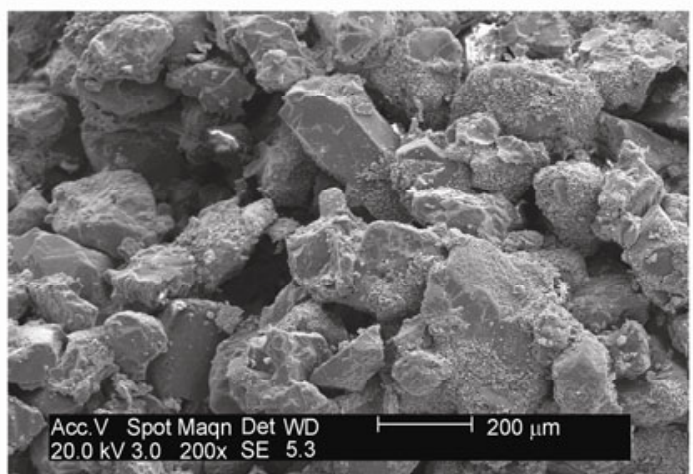

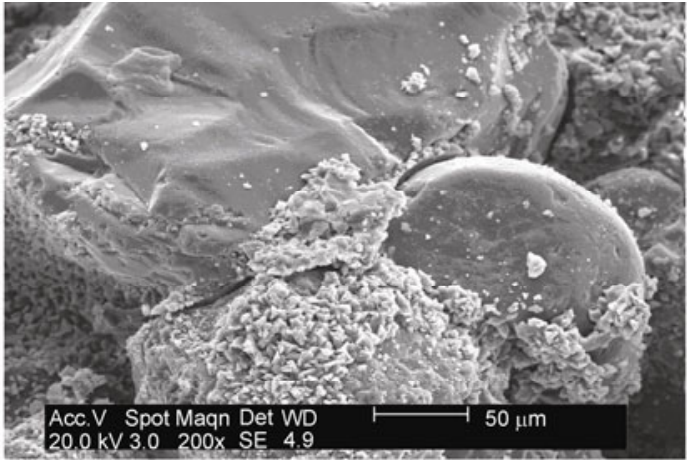
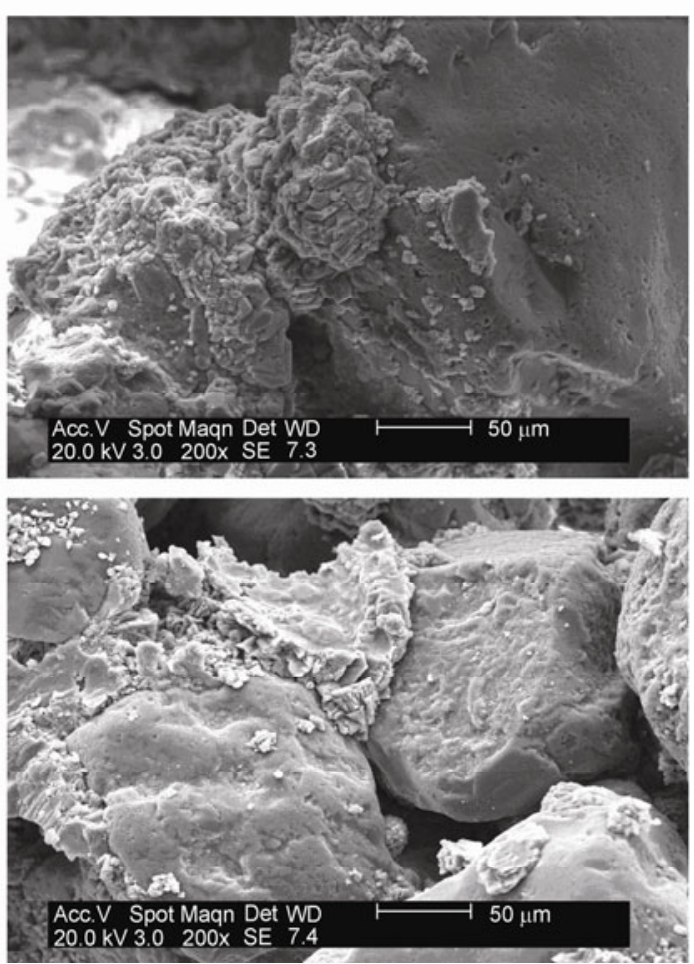

Figure 6 SEM photos of bio-sandstones. (a) 1\# sandstone cemented by microbe cement; (b) 2\# sandstone cemented by microbe cement; (c) sandstone cemented by microbe cement. 
largest strength (11.7 MPa), followed by $1 \#(7.8 \mathrm{MPa})$ and 3\# (4.5 MPa). The biosandstone samples after failure are shown in Figure 5(b). The weak zones of $1 \#$ and $3 \#$ bio-sandstone were at the top while 2\# sandstone had good uniformity throughout the whole column.

The precipitated calcite contents in $1 \#$ and $3 \#$ biosandstones were $25.7 \mathrm{~g}$ and $18.2 \mathrm{~g}$ respectively, which was lower than that of 2 \# bio-sandstone $(36.3 \mathrm{~g})$.

Figure 6 shows micrographs of the samples. Most of the microbial induced calcium carbonate crystals seen in Figure 6(b) have precipitated at the surfaces of loose sand particles and between the sand grains. The porosity of $2 \#$ biosandstone was less than that of $1 \#$ and $3 \#$ bio-sandstone. This may be because the quantity of microbes absorbed in 2\# sandstone was more than $1 \#$ and $3 \#$ so that the microbial induced precipitated calcite content in $2 \#$ sandstone was the highest. Therefore, the microstructure and compressive strength of $2 \#$ sandstone cemented by microbe cement were superior to those of $1 \#$ and $3 \#$ samples.

\subsection{Porosity and pore size distribution}

The pore size distributions of the representative sandstonescemented by microbe cement were measured by MIP, and the results are shown in Figure 7. The average pore size of $2 \#$ bio-sandstone ranged from 25 to $30 \mu \mathrm{m}$, that of $1 \#$ bio-sandstone was in the range of 27 to $32 \mu \mathrm{m}$ and $3 \#$ bio-sandstone had the largest pore size (from 32 to $36 \mu \mathrm{m}$ ). The results showed that the difference of pore size diameter in three samples was not evident. Besides, the porosity of sand before and after cementation by microbe cement was shown in Table 2, which shows that treatment with microbe cement decreased the porosity. The greatest reduction in porosity was experienced by $2 \#$. This may be attributed to the larger amount of microbially induced precipitated calcite in 2\# sandstone and the bio-mediated calcite crystal size was smallest in the $2 \#$ sandstone sample.

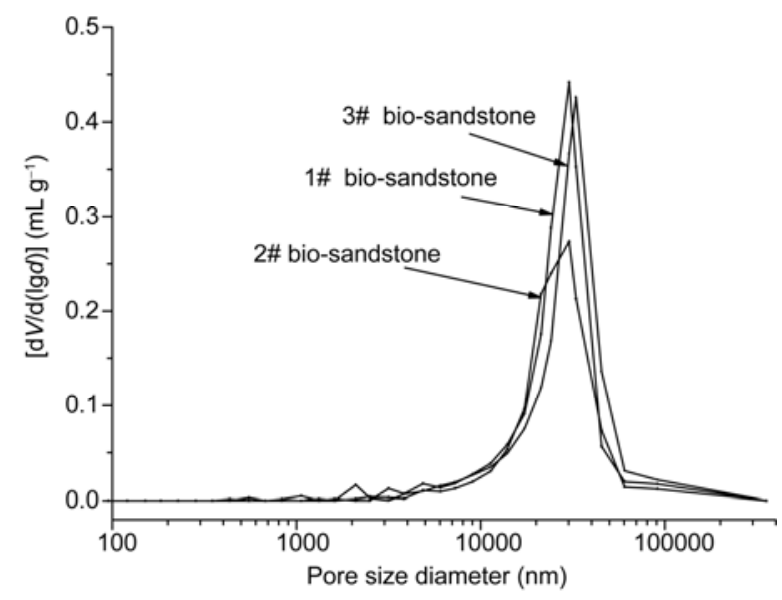

Figure 7 Pore size distributions of the sandstones cemented by microbe cement at age 20 days.

\subsection{Correlation among porosity, mechanical properties and calcium carbonate content}

To determine the effect of calcium carbonate precipitation on the mechanical properties of the treated material, the porosity and strength results were correlated with the calcium carbonate content of each of the tested samples (Figure 8). Low calcite contents did not significantly improve the strength of the samples. The highest strength in $2 \#$ bio-sandstone was $11.7 \mathrm{MPa}$, which was measured on the same sample as the maximum amount of $\mathrm{CaCO}_{3}$. Figure 8 also shows that the content of calcium carbonate had a clear effect on the porosity of the microbe cementitious material and a reasonably linear relationship between the two parameters was observed. At the maximum calcium carbonate content (36.3 $\mathrm{g} \mathrm{CaCO}_{3}$ ) in $2 \#$ bio-sandstone, the column porosity was decreased to $55 \%$ of that of the untreated loose sand grains.

\section{Conclusions}

The successful development of a method for cementation of loose particles based on microbe cement has been presented. The following conclusions were reached.

(1) The feasibility of binding loose sand particles with microbe cement was demonstrated to produce a new cementitious material to replace Portland cement, and the cementation mechanism of this microbe cement was elaborated in detail.

(2) A significant strength increase was achieved after the treatment. The extent of improvement depended on the

Table 2 Porosity of bio-sandstone

\begin{tabular}{cccc}
\hline \multirow{2}{*}{ Label } & $\begin{array}{c}\text { Initial porosity } \\
(\%)\end{array}$ & $\begin{array}{c}\text { Final porosity } \\
(\%)\end{array}$ & $\begin{array}{c}\text { Decrease at age of } 20 \mathrm{~d} \\
(\%)\end{array}$ \\
\hline 1\# & 42.1 & 29.2 & 30.6 \\
$2 \#$ & 43.1 & 23.7 & 45.0 \\
$3 \#$ & 42.6 & 33.7 & 20.9 \\
\hline
\end{tabular}

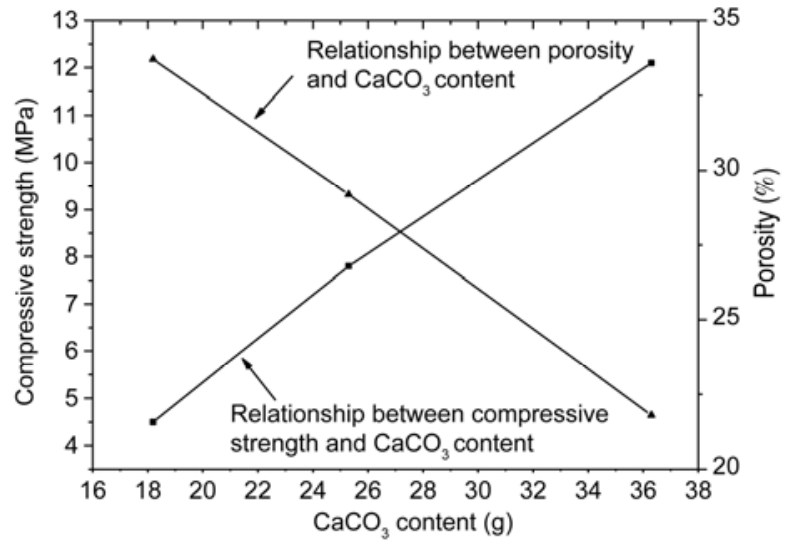

Figure 8 Correlation among calcite content, compressive strength and porosity. 
precipitated calcite content and porosity, which in turn depended on the bacteria solution content, bacterial activity, supply of substrate reactants and so on.

(3) The effectiveness of microbe cement as a binder for loose particles did not appear to be limited to small scale samples; it may be possible to apply this technique to large-scale improvement work.

This work was supported by the National Natural Science Foundation of China (51072035), Ph.D. Program's Foundation of Ministry of Education of China (20090092110029), Research Innovation Program for College Graduates of Jiangsu Province (CXZZ 0145) and Scientific Research Foundation of Graduate School of Southeast University (YBJJ1127).

1 Le Metayer-Levrel G, Castanier S, Orial G, et al. Applications of bacterial carbonatogenesis to the protection and regeneration of limestones in buildings and historic patrimony. Sediment Geol, 1999, 126: 25-34

2 Nemati M, Voordouw G. Modification of porous media permeability, using calcium carbonate produced enzymatically in situ. Enzyme Microb Technol, 2003, 33: 635-642

3 DeJong J T, Fritzges M B, Nusslein K. Microbially induced cementation to control sand response to undrained shear. J Geotech Geoenviron Eng, 2006, 132: 1381-1392

4 De Jong J T, Brina M M, Brian C M, et al. Bio-mediated soil improvement. Ecolo Eng, 2010, 36: 197-210

5 Whiffin V S. Microbial $\mathrm{CaCO}_{3}$ precipitation for the production of Biocement. Dissertation for Doctoral Degree. Western Australia: Murdoch University, 2004

6 Whiffin V S, Van Paassen L A, Harkes M P. Microbial carbonate precipitation as a soil improvement technique. Geomicrobiol J, 2007, 24: $417-423$

7 Ivanov V, Chu J. Applications of microorganisms to geotechnical engineering for bioclogging and biocementation of soil in situ. Rev Environ Sci Biotechnol, 2008, 7: 139-153

8 De Muynck W, De Belie N, Verstraete W. Microbial carbonate precipitation in construction materials: A review. Ecol Eng, 2010, 36: $118-136$

9 De Muynck W, Verbeken K, De Belie N, et al. Influence of urea and calcium dosage on the effectiveness of bacterially induced carbonate precipitation on limestone. Ecol Eng, 2010, 36: 99-111

10 De Muynck W, Debrouwer D, De Belie N, et al. Bacterial carbonate precipitation improves the durability of cementitious materials. Cem
Concr Res, 2008, 38: 1005-1014

11 Qian C X, Wang J Y, Wang R X, et al. Corrosion protection of cement-based building materials by surface deposition of $\mathrm{CaCO}_{3}$ by Bacillus pasteurii. Mater Sci Eng C, 2009, 29: 1273-1280

12 Ramachandran S K, Ramakrishnan V, Bang S S. Remediation of concrete using micro-organisms. ACI Mater J, 2001, 1: 3-9

13 Ferris F G, Setehmeir L G. Bacteriogenic mineral plugging. United States Patent, 664769, 1992

14 Nemati M, Greene E A, Voordouw G. Permeability profile modification using bacterially formed calcium carbonate: Comparison with enzymic option. Process Biochem, 2005, 40: 925-933

15 Ferris F G, Phoenix V, Fujita Y, et al. Kinetics of calcite precipitation induced by ureolytic bacteria at $10^{\circ} \mathrm{C}$ to $20^{\circ} \mathrm{C}$ in artificial groundwater. Geochem Cosmochim Acta, 2003, 67: 1701-1722

16 Fujita Y, Ferris F G, Lawson R D, et al. Calcium carbonate precipitation by ureolytic subsurface bacteria. Geomicrobiol J, 2000, 17: 305-318

17 Warren L A, Maurice P A, Parmar N, et al. Microbially mediated calcium carbonate precipitation: Implications for interpreting calcite pecipitation and for solid-phase capture of inorganic contaminants. Geomicrobiol J, 2001, 18: 93-115

18 Chaturvedi S, Chandra R, Rai V. Isolation and characterization of Phragmites australis (L) rhizosphere bacteria from contaminated site for bioremediation of colored distillery effluent. Ecol Eng, 2006, 27: 202-207

19 Simon M A, Bonner J S, Page C A, et al. Evaluation of two commercial bioaugmentation products for enhanced removal of petroleum from a wetland. Ecol Eng, 2004, 22: 263-277

20 Bachmeier K L, Williams A E, Warmington J R, et al. Urease activity in microbiologically-induced calcite precipitation. J Biotechnol, 2002, 93: $171-181$

21 Ferris F G, Stechmeier L G, Kantzas A, et al. Bacteriogenic mineral plugging. J Can Pet Technol, 1996, 35: 56-61

22 Ramakrishnan V, Ramesh K P, Bang S S. Bacterial concrete. In: Proc of SPIE-Int Society of Optical Engineering, 2001, 4234: 168-176

23 Morse J W. The kinetics of calcium carbonate dissolution and precipitation. In: Reeder R J, ed. Carbonates: Mineralogy and Chemistry, vol. 11. Washington, DC: Mineralogic Society of America, 1983. 227-264

24 Kantzas A, Stehmeier L, Marentette D F, et al. A novel method of sand consolidation through bacteriogenic mineral plugging. In: Jha $\mathrm{K}$ N, Maurits F M, eds. Proceedings of Annual Technical Meeting, 1992 Jun 7-10 Canada, Calgary: Society of Petroleum Engineers, 1992. 46

25 Qian C X, Pan Q F, Wang R X. Cementation of sand grains based on carbonate precipitation induced by microorganism. Sci China Tech Sci, 2010, 53: 2198-2206

Open Access This article is distributed under the terms of the Creative Commons Attribution License which permits any use, distribution, and reproduction in any medium, provided the original author(s) and source are credited. 